\title{
Microbial Quality of Sliced Pawpaw (Carica papaya) and Watermelon (Citrullus lanatus) Sold on Some Streets of Accra Metropolis, Ghana
}

\author{
Michael Olu-Taiwo, Baakwa Miah De-Graft, and Akua Obeng Forson \\ Department of Medical Laboratory Science, School of Biomedical and Allied Health Sciences, College of Health Sciences, \\ University of Ghana, Korle-bu, Ghana
}

Correspondence should be addressed to Akua Obeng Forson; obeng.akua@yahoo.com

Received 20 October 2020; Revised 19 November 2020; Accepted 12 January 2021; Published 27 January 2021

Academic Editor: Clemencia Chaves Lopez

Copyright ( $) 2021$ Michael Olu-Taiwo et al. This is an open access article distributed under the Creative Commons Attribution License, which permits unrestricted use, distribution, and reproduction in any medium, provided the original work is properly cited.

\begin{abstract}
In most African countries, street vending of fruits is prevalent and the likelihood of predisposing consumers to microbial contamination is very high. This study aimed to determine various bacteria and risk factors that are associated with fruits sold by street vendors in Accra. Sliced watermelons and pawpaws were randomly purchased from selected suburbs in Greater Accra Region of Ghana. One gram (1 g) of each watermelon and pawpaw was homogenized in $9 \mathrm{ml}$ of sterile peptone water, and $0.1 \mathrm{ml}$ from each serial dilutions of each fruit was spread on plate count agar, blood agar, and MacConkey agar plates for total aerobic counts and coliform counts. Agar plates were incubated at $33-37^{\circ} \mathrm{C}$ for $18-24 \mathrm{~h}$. Bacterial identification was done by standard bacteriological methods. Additionally, questionnaires were administered to the vendors to gather data on food hygiene and knowledge on foodborne illness. The study revealed that although some of the fruit vendors were educated on food hygiene, most sold fruits were contaminated with mean total aerobic plate counts of $2.6 \times 10^{5}-8.1 \times 10^{5} \mathrm{CFU} \mathrm{g}^{-1}$ and $3.7 \times 10^{4}-7.1 \times 10^{4} \mathrm{CFU} \mathrm{g}$ for watermelon and pawpaw. The mean coliform counts for pawpaw and watermelon ranged between $1.2 \times 10^{3}-8.1 \times 10^{3} \mathrm{CFU} \mathrm{g}^{-1}$ and $1.6 \times 10^{4}-3.1 \times 10^{4} \mathrm{CFU} \mathrm{g}^{-1}$, respectively. Overall, mean aerobic counts and mean coliform counts were not significantly different among vendors in selected locations $(p>0.05)$. However, predominant bacteria isolated included Enterobacter species (33.3\%), Citrobacter sp. (20.0\%), and Klebsiella sp. (15.9\%). The study revealed that watermelon and pawpaw sold on the streets in Accra could be possible source of foodborne illness. Therefore, street food vendors must be educated on food hygiene protocols and measures to improve microbial quality of street vended fruits.
\end{abstract}

\section{Introduction}

In the last few years, there has been a substantial increment in consumption of sliced/ready-to-eat fruits in Ghana, due to its affordability in small quantity, convenience, freshness, easy accessibility, and nutritional benefits [1-3]. The high consumption pattern of sliced fruits has led to an escalation of foodborne illness [4]. Sliced fruits particularly consumed in Accra include pawpaw, pineapple, watermelon, apple, and mango. Street vendors often slice fresh fruits by peeling and cutting them into pieces and packing them in small polythene bags to be sold to consumers for immediate consumption without necessarily rinsing or washing them because they have already been packaged. Most of the street vendors have a low educational level, unlicensed and untrained in food hygiene [2]. Despite the benefits derived from daily consumption of fruits, they are prone to microbial contaminations in addition to the associated risk of disease transmission to which consumers may be exposed. Furthermore, various pathogenic bacterial species have been associated with contaminations of fruits and vegetables as evidenced by their isolation from several fruits and vegetables [1, 5, 6]. According to CDC [7], watermelon caused Salmonella outbreak in 2002 and 2006 in the United States. Likewise, in 2011, watermelon from Brazil was implicated in outbreak of Salmonella infections in Europe, with 63 
confirmed cases of food poisoning [8]. In Nigeria, a study to determine the microbiological quality of sliced watermelon sold by street vendors revealed an average aerobic counts of $0.1-2.3 \times 10^{5} \mathrm{CFU} \mathrm{g}^{-1}$ [3]. Another study in Nigeria has isolated Staphylococcus aureus, Klebsiella sp., Salmonella sp., and Escherichia coli in ranges between $9.0 \times 10^{5}$ and $3.0 \times 10^{7} \mathrm{CFU} / \mathrm{ml}$ from carrot, runner bean, cucumber, fresh cut pineapple, green pepper, cabbage, spring onions, lettuce, watermelon, and apple [6]. Furthermore, Pesewu et al. [9] study on raw-mixed vegetable salads in the Accra Metropolis reported a high level of bacterial contamination with Escherichia coli (36\%), Staphylococcus aureus (33\%), Klebsiella sp. (17\%), and Bacillus sp. (15\%). However, despite all the awareness of microbial contamination of fruits and vegetables, there is paucity of information in Ghana on potential risk factors and microbial quality of street vended sliced polyethylene packaged fruits. This study aimed to determine the bacterial quality of polyethylene packed sliced pawpaw and watermelon sold by street vendors in Accra and to assess risk factors associated with their consumption.

\section{Materials and Methods}

2.1. Study Participant. Packaged sliced watermelon and pawpaw were randomly purchased and sampled from March to April, 2017. Street fruit vendors were selected at Korle-Bu, University of Ghana (night market), Agbogbloshie, Shiashi, and Accra Tema Station, all in the Greater Accra Region. Only prewashed/sliced watermelon and pawpaw packaged in polyethylene bags or transparent microwave bowls by vendor were collected. A total of 45 sliced watermelons and 45 sliced pawpaws were used for this study. Nine samples each of pawpaw and watermelon were taken from each location. The samples were transported on ice packs within two hours to the University of Ghana, School of Biomedical and Allied Health Sciences Microbiology Laboratory. In addition, questionnaires were administered to vendors to gather data on vendor's personal hygiene, food hygiene, knowledge on foodborne illness and their causes.

2.2. Bacteriological Analysis of Samples. Approximately, $1 \mathrm{~g}$ of fresh cut fruits (pawpaw and watermelon) was sliced with a sterile knife and added to $9 \mathrm{ml}$ of $0.1 \%$ buffered peptone water to prepare homogenate suspension using stomacher bag (Seward, UK). This was followed by a ten-fold serial dilution of $10^{-2}$ to $10^{-4}$ of homogenized samples as described by Nwachukwu and Osuocha [2]. An aliquot of $0.1 \mathrm{ml}$ from each serial dilutions was inoculated onto plate count agar (Oxoid, Cambridge, UK), blood agar (Oxoid, Cambridge, UK), and MacConkey agar (Oxoid, Cambridge, UK) using the spread plate technique for total viable aerobic count and coliform count. Inoculation was done in duplicates, and the plates were incubated at $33-37^{\circ} \mathrm{C}$ for $24-48 \mathrm{~h} \mathrm{[2].}$

2.3. Bacteria Identification. Identification of bacterial isolates was done by first subculturing from primary culture plates to obtain pure culture colonies. Bacteria identification from pure culture plates was based on colonial morphology, and a representative colony on each plate was picked and Gram stained and further tested using indole, methyl red, citrate, oxidase, Voges-Proskauer tests, urease and coagulase tests [10]. An API 20E identification system (bioMerieux SA, Marcy l"Etoile, France) was also used to confirm all the Gram negative isolates.

2.4. Bacterial Colony Enumeration. Enumeration of bacterial colonies was carried out from plate count agar for total aerobic count and total coliform count from MacConkey agar. After incubation, colonies that were in the range between 30 and 300 were considered.

2.5. Data Analysis. Bacterial counts were calculated as colony forming units per gram $\left(\mathrm{CFU} \mathrm{\textrm {g } ^ { - 1 }}\right.$ ) and then converted into $\log 10$ values. Descriptive statistics were computed using the Microsoft Excel data analysis, Fischer's exact, and chi-square, and one-way ANOVA was analyzed using GraphPad Prism software, version 6, to find the statistical difference $(P<0.05)$. Statistical significance was set at a $P$ value of $<0.05$.

\section{Result}

3.1. Demographics and Characteristics of Fruit Vendors. All the watermelon vendors for this study were females. However, $71.1 \%$ vendors were aged between 30 and 49 years, $24.4 \%$ vendors were below 30 years old, and $4.4 \%$ of vendors were above 50 years old (Table 1$)$. Sixty-eight percent $(31 / 45)$ of the vendors had received formal education with the commonest level of education being junior high school (31.1\% (14)). Most of the watermelon vendors were mobile [42.2\% (19/45)], and 26.7\% (12/45) were stationary at their various vending sites (Table 1$)$.

Ninety-seven percent of the pawpaw vendors were females, and $2.2 \%$ were males. Fifteen percent of the pawpaw fruit vendors were below the age of 30 years, $13.3 \%$ were above 50 years, and $71.1 \%$ vendors were between 30 and 49 years (Table 1). Twenty percent of the vendors had attended basic school, $15.6 \%$ had junior high school, $20.0 \%$ had senior high school, $2.2 \%$ had tertiary education, and $42.2 \%$ gave no response regarding their educational level. Most $(66.7 \%)$ of the vendors were stationary, and $24.4 \%$ were mobile vendors (Table 1).

3.2. Risk Factors and Personal Hygiene of Fruit Vendors. Regarding personal hygiene, $15.6 \%$ of the watermelon vendors washed their hands at least 3 times a day, while 44.4\% washed their hands more than 3 times in a day (Table 2). Seventy-three percent of the vendors washed their hands before and after peeling or slicing the watermelons. Also, $62.2 \%(28 / 45)$ vendors washed their fruits before packaging and slicing, while $11.1 \%$ did not. Sixty-eight percent of the vendors washed their knife before using them, and $71.1 \%$ washed their tray before using them. Seventythree percent of the watermelon vendors used tap water to wash their watermelon and packaged their sliced 
TABle 1: Demographic characteristics of the fruit vendors.

\begin{tabular}{|c|c|c|c|}
\hline Parameters & Site & $\begin{array}{c}\text { Watermelon } \\
\text { No. }(\%)\end{array}$ & $\begin{array}{l}\text { Pawpaw } \\
\text { No. (\%) }\end{array}$ \\
\hline \multirow[t]{6}{*}{ Selling point of fruit } & KB & $21(46.7)$ & $12(26.7)$ \\
\hline & $\mathrm{AB}$ & $13(28.9)$ & $8(17.8)$ \\
\hline & UNM & $7(15.6)$ & $13(28.9)$ \\
\hline & ATS & $2(4.4)$ & $6(13.3)$ \\
\hline & $\mathrm{SH}$ & $2(4.4)$ & $3(6.7)$ \\
\hline & $\mathrm{TM}$ & 0 & $3(6.7)$ \\
\hline \multicolumn{4}{|l|}{ Sex } \\
\hline & Male & 0 & $1(2.2)$ \\
\hline & Female & $45(100)$ & $44(97.8)$ \\
\hline \multicolumn{4}{|l|}{ Age } \\
\hline & $<30$ & $11(24.4)$ & $7(15.6)$ \\
\hline & $30-49$ & $32(71.1)$ & $32(71.1)$ \\
\hline & $\geq 50$ & $2(4.4)$ & $6(13.3)$ \\
\hline \multicolumn{4}{|l|}{ Educational status } \\
\hline & Basic school & $11(24.4)$ & $9(20)$ \\
\hline & JHS & $14(31.1)$ & $7(15.6)$ \\
\hline & SHS & $5(11.1)$ & $9(20.0)$ \\
\hline & Tertiary & $1(2.2)$ & $1(2.2)$ \\
\hline & No answer & $14(31.1)$ & $19(42.2)$ \\
\hline \multicolumn{4}{|l|}{ Type of vendor } \\
\hline & Stationary & $12(26.7)$ & $30(66.7)$ \\
\hline & Mobile & $19(42.2)$ & $11(24.4)$ \\
\hline & No answer & $14(31.1)$ & $4(8.9)$ \\
\hline \multicolumn{4}{|c|}{ Vending years' experience } \\
\hline & $5-10$ & $21(46.7)$ & $10(22.2)$ \\
\hline & $11-20$ & $8(17.7)$ & $9(20.0)$ \\
\hline & $>20$ & $1(2.2)$ & $6(13.3)$ \\
\hline
\end{tabular}

ATS: Accra Team Station; AB: Agbogbloshie; UNM: University of Ghana Night Market; SH: Shiashi; KB: Korle-Bu; TM: Tuesday Market.

TABLE 2: Fruit vendors of packaged pawpaw and watermelon and associated risk factors.

\begin{tabular}{|c|c|c|c|}
\hline Risk factors & & Watermelon, $n(\%)$ & Pawpaw, $n(\%)$ \\
\hline Hand washing & $\begin{array}{l}\text { At least three times daily } \\
\text { More than three times daily } \\
\text { Wash hands before peeling fruits } \\
\text { Wash hands after peeling fruits }\end{array}$ & $\begin{array}{c}7(15.6) \\
20(44.4) \\
\text { Yes }=33(73.3), \text { no }=12(26.7) \\
\text { Yes }=33(73.3), \text { no }=12(26.7)\end{array}$ & $\begin{array}{c}6(13.3) \\
16(35.6) \\
\text { Yes }=34(75.6), \mathrm{No}=11(24.4) \\
\text { Yes }=34(75.6), \mathrm{No}=11(24.4)\end{array}$ \\
\hline Handling procedures & $\begin{array}{c}\text { Wash fruit before slicing and packaging } \\
\text { Wash knife before using } \\
\text { Wash display tray before usage }\end{array}$ & $\begin{array}{l}\text { Yes }=28(62.2), \text { no }=16(35.6) \\
\text { Yes }=31(68.9), \text { no }=13(28.9) \\
\text { Yes }=32(71.1), \text { no }=14(31.1)\end{array}$ & $\begin{array}{l}\text { Yes }=30(60.7), \text { no }=15(33.3) \\
\text { Yes }=33(73.3), \text { no }=12(26.7) \\
\text { Yes }=31(68.9), \text { no }=14(31.1)\end{array}$ \\
\hline Water for handling & $\begin{array}{l}\text { Tap water } \\
\text { No answer }\end{array}$ & $\begin{array}{l}33(73.3) \\
12(26.7)\end{array}$ & $\begin{array}{l}34(75.6) \\
11(24.4)\end{array}$ \\
\hline Type of package used & $\begin{array}{l}\text { Polyethylene bag } \\
\text { No answer }\end{array}$ & $\begin{array}{l}33(73.3) \\
12(26.7) \\
\end{array}$ & $\begin{array}{l}34(75.6) \\
11(24.4) \\
\end{array}$ \\
\hline Methods of storage & $\begin{array}{l}\text { All fruits are sold out } \\
\text { Discarded } \\
\text { Covered up in a room }\end{array}$ & $\begin{array}{c}27(60.0) \\
6(13.3) \\
12(26.7) \\
\end{array}$ & $\begin{aligned} & 34(75.6) \\
& 3(6.7) \\
& 8(17.8) \\
&\end{aligned}$ \\
\hline Courses on food hygien & $\begin{array}{c}\text { Yes } \\
\text { No } \\
\text { No answer }\end{array}$ & $\begin{array}{c}6(13.3) \\
25(55.6) \\
14(31.1) \\
\end{array}$ & $\begin{aligned} & 4(8.9) \\
& 21(46.7) \\
& 20(44.4) \\
&\end{aligned}$ \\
\hline How long ago the cou & $\begin{array}{c}\text { as attended } \\
\qquad 1 \text { year } \\
>2 \text { years } \\
\text { No response }\end{array}$ & $\begin{aligned} 5 & (11.1) \\
1 & (2.2) \\
39 & (86.7)\end{aligned}$ & $\begin{array}{c}4(8.9) \\
0 \\
41(91.1)\end{array}$ \\
\hline
\end{tabular}


watermelon with polyethylene bags. Only $13.3 \%$ of the vendors had attended a course on food hygiene, but $86.6 \%$ had not attended any course on food hygiene.

Thirteen percent of the pawpaw vendors washed their hands at least three times in a day, while $35.6 \%$ washed their hands more than 3 times in a day. Twenty-two percent of the pawpaw vendors claimed they had vending experience of less than 10 years, $20 \%$ had between 10 and 20 years, and $13.3 \%$ had vending experience of more than 20 years. Most (75.6\%) of the pawpaw vendors washed their hands before and after peeling and slicing the pawpaws (Table 2). Sixty-six percent of the vendors washed their fruits before slicing and packaging them, and $33.3 \%$ did not wash their fruits before slicing and packaging. Also, $73.3 \%$ of the vendors washed their knives before using them and $68.9 \%$ said they washed their trays before using them. Concerning courses on food hygiene, only $8.9 \%$ had attended some courses on food hygiene at the time of the study. Six percent of the vendors kept leftover sliced fruits covered up on the table for the next day, while $17.8 \%$ of the vendors discarded any leftover fruits at the close of the day. No statistical association was found for the different assessed risk factors associated with water melon and pawpaw vendors $(P>0.05)$.

\subsection{Bacteriological Count}

3.3.1. Mean Total Aerobic Count. Overall, the mean aerobic count for pawpaw and watermelon samples analyzed ranged between $3.7 \times 10^{4}$ and $8.1 \times 10^{5} \mathrm{CFU} \mathrm{g}^{-1}$. The mean aerobic count for watermelon ranged between $2.6 \times 10^{5}$ and $8.1 \times 10^{5} \mathrm{CFU} \mathrm{g}^{-1}$, while the mean aerobic count for pawpaw ranged between $3.7 \times 10^{4} \mathrm{CFU} \mathrm{g}^{-1}$ and $8.3 \times 10^{4} \mathrm{CFU} \mathrm{g}^{-1}$. The maximum mean aerobic count was observed in watermelon and pawpaw from Korle-Bu $\left(8.1 \times 10^{5}\right.$ and $\left.8.3 \times 10^{4} \mathrm{CFU} \mathrm{g}^{-1}\right)$. While the minimum mean aerobic count was observed in pawpaw from Accra Tema Station $\left(3.7 \times 10^{4} \mathrm{CFU} \mathrm{g}^{-1}\right)$. Mean aerobic counts were not significantly different among vendors in selected locations $(p>0.05)($ Table 3$)$.

3.3.2. Mean Total Coliform Count. Overall, the mean coliform count for pawpaw and watermelon ranged between $1.2 \times 10$ and $1.6 \times 10^{4} \mathrm{CFU} \mathrm{g}^{-1}$. The maximum mean coliform count was observed in watermelon from Korle-Bu $\left(1.6 \times 10^{4} \mathrm{CFU} \mathrm{g}^{-1}\right)$, while minimum mean coliform count was exhibited in pawpaw from Shiashi $\left(1.2 \times 10^{3} \mathrm{CFU} \mathrm{g}^{-1}\right)$. Mean coliform counts were not significantly different among vendors in selected locations $(p>0.05)$ (Table 3$)$.

3.4. Bacteria Isolated from Packaged Sliced Watermelons at Various Locations. Bacteria isolated from sliced watermelons were Citrobacter koseri (1.5\%), Citrobacter sp. (19.4\%), Enterobacter sp. (28.4\%), Klebsiella pneumoniae (7.5\%), Klebsiella sp. (20.9\%), Proteus vulgaris (3.0\%), Pseudomonas sp. (1.5\%), Staphylococcus aureus (7.5\%), and Staphylococcus epidermidis (10.5\%) (Table 4).
Comparing isolates from the various selling locations, Korle-Bu had the highest number of isolates (45.0\%) (Table 4). Bacterial isolates from Korle-Bu include Citrobacter sp. (7), Enterobacter sp. (9), Klebsiella pneumoniae (1), Klebsiella sp. (8), Proteus vulgaris (2), Staphylococcus aureus (1), and Staphylococcus epidermidis (2). Thirty percent 30\% isolates which included Citrobacter koseri (1), Citrobacter sp. (3), Enterobacter sp. (6), Klebsiella pneumoniae (1), Klebsiella sp. (4), Pseudomonas sp. (1), Staphylococcus aureus (3), and Staphylococcus epidermidis (1) were isolated from watermelon from Agbogbloshie Market.

3.5. Bacteria Isolated from Sliced Pawpaws at Various Sales Locations. Bacteria isolated from pawpaws were Citrobacter koseri (4.6\%), Citrobacter sp. (20.0\%), Enterobacter sp. (38.5\%), Klebsiella pneumoniae (6.2\%), Klebsiella sp. (10.8\%), Pseudomonas sp. (3.1\%), Staphylococcus epidermidis (1.5\%), and Staphylococcus aureus (15.4\%) (Table 4).

Pawpaw sampled from Korle-Bu had the highest contamination of $31 \%$ (21) including Citrobacter koseri (1), Citrobacter sp. (4), Enterobacter sp. (8), Klebsiella pneumoniae (1), Klebsiella sp. (4), and Staphylococcus aureus (3). Also, a total of $29 \%$ (19) were obtained from University of Ghana (night market) and from Shiashi, and eight isolates (12\%) were from pawpaw, whilst $17 \%$ (11) of isolates were obtained from Agbogbloshie, including Citrobacter koseri (2), Citrobacter sp. (2), Enterobacter sp. (4), and Klebsiella sp. (3). However, 9\% (6) of isolates were obtained from Accra Tema Station, including Citrobacter sp. (2), Enterobacter sp. (3), and Klebsiella pneumoniae (1).

\section{Discussion}

In this study, $98 \%$ of street fruit vendors were females and most of them were within $30-49$ years of age $(71.1 \%)$ with some form of formal education but with limited knowledge on food hygiene and safety. These study findings are in agreement with Odonkor et al. [11] and Donkor et al. [12] findings that reported $76 \%$ and $98.4 \%$ of females are involved in the business of street vending of foods. In contrast to these findings, a study by Mudey et al. [13] in India, has reported $69.4 \%$ of males were engaged in ready-to-eat foods. A knowledge in food hygiene and safety and the consequences of contaminated or spoiled fruits on the health of the consumers should be a major concern to the business of fruit vendors and the state at large [14]. In Ghana, metropolitan assemblies collaborate with the Food and Drug Authority (FDA) and officials of respective municipal and district assemblies for street vendors to obtain vending authorization [15]. These authorization includes obtaining a development and building permit (DBP) from the Accra Metropolitan Assembly (AMA) and business operating permit (BOP) from health inspectors from the Environmental Health Department following an inspection of the hygiene of the place of vending and a valid personal health certificate issued by a recognized health institution $[14,15]$. However, compared to other countries, there is no need to attend a hazard analysis and critical control point (HACCP) 
TABLE 3: Mean aerobic counts and mean coliform counts of packaged pawpaw and watermelon from various locations.

\begin{tabular}{|c|c|c|c|c|c|c|c|c|c|c|}
\hline Location & $\mathrm{N}$ & $\begin{array}{c}\text { Mean } \\
\text { Ac CFU g } \\
\text { Pawpaw }\end{array}$ & $\begin{array}{l}\text { Mean } \\
\text { Log } 10\end{array}$ & $\begin{array}{l}\quad \text { Mean } \\
\text { Ac CFU g } \\
\text { Watermelon }\end{array}$ & $\begin{array}{l}\text { Mean } \\
\text { Log10 }\end{array}$ & $\mathrm{N}$ & $\begin{array}{c}\text { Mean } \\
\text { CC CFU g } \\
\text { Pawpaw }\end{array}$ & $\begin{array}{l}\text { Mean } \\
\text { Log10 }\end{array}$ & $\begin{array}{l}\quad \text { Mean } \\
\text { Ac CFU g } \\
\text { Watermelon }\end{array}$ & $\begin{array}{l}\text { Mean } \\
\text { Log } 10\end{array}$ \\
\hline KB & 9 & $7.1 \times 10^{4}$ & 4.85 & $8.1 \times 10^{5}$ & 5.90 & 9 & $8.1 \times 10^{3}$ & 4.14 & $2.4 \times 10^{4}$ & 4.38 \\
\hline $\mathrm{AB}$ & 9 & $8.3 \times 10^{4}$ & 4.91 & $7.3 \times 10^{5}$ & 5.80 & 9 & $6.2 \times 10^{3}$ & 3.87 & $1.5 \times 10^{4}$ & 4.17 \\
\hline UNM & 9 & $5.4 \times 10^{4}$ & 4.73 & $6.3 \times 10^{5}$ & 5.87 & 9 & $4.6 \times 10^{3}$ & 3.70 & $3.1 \times 10^{4}$ & 4.49 \\
\hline $\mathrm{SH}$ & 9 & $4.3 \times 10^{4}$ & 4.60 & $5.3 \times 10^{5}$ & 5.73 & 9 & $1.2 \times 10^{3}$ & 3.07 & $1.4 \times 10^{4}$ & 4.14 \\
\hline ATS & 9 & $3.7 \times 10^{4}$ & 4.52 & $2.6 \times 10^{5}$ & 5.41 & 9 & $2.4 \times 10^{3}$ & 3.38 & $1.6 \times 10^{4}$ & 4.20 \\
\hline Total & 45 & & & & & 45 & & & & \\
\hline
\end{tabular}

${ }^{*}$ Mean aerobic and mean coliform counts were not significantly different among vendors in selected locations $(p>0.05)$. ATS: Accra Team Station; AB: Agbogbloshie; UNM: University of Ghana Night Market; SH: Shiashi; KB: Korle-Bu; AC: aerobic count; CC: coliform count.

TABLE 4: Frequency of isolates from packaged watermelon and pawpaw at various locations.

\begin{tabular}{|c|c|c|c|c|c|c|c|c|c|c|c|}
\hline \multirow{2}{*}{ Isolated obtained } & \multicolumn{5}{|c|}{ Packaged watermelon } & \multicolumn{6}{|c|}{ Packaged pawpaw } \\
\hline & ATS & $\mathrm{AB}$ & UNM & $\mathrm{SH}$ & KB & ATS & $\mathrm{Ab}$ & UNM & $\mathrm{SH}$ & KB & Total (\%) \\
\hline Citrobacter koseri & 0 & 1 & 0 & 0 & 0 & 0 & 2 & 0 & 0 & 1 & $4(3.0)$ \\
\hline Citrobacter sp. & 1 & 3 & 2 & 0 & 7 & 2 & 2 & 3 & 2 & 4 & $26(20.0)$ \\
\hline Enterobacter sp. & 1 & 6 & 1 & 2 & 9 & 3 & 4 & 9 & 1 & 8 & $44(33.3)$ \\
\hline Klebsiella pneumoniae & 1 & 1 & 2 & 0 & 1 & 1 & 0 & 1 & 1 & 1 & $9(6.8)$ \\
\hline Klebsiella sp. & 0 & 4 & 1 & 1 & 8 & 0 & 3 & 0 & 0 & 4 & $21(15.9)$ \\
\hline Proteus vulgaris & 0 & 0 & 0 & 0 & 2 & 0 & 0 & 0 & 0 & 0 & $2(1.52)$ \\
\hline Pseudomonas sp. & 0 & 1 & 0 & 0 & 0 & 0 & 0 & 0 & 2 & 0 & $3(2.3)$ \\
\hline Staphylococcus aureus & 0 & 3 & 1 & 0 & 1 & 0 & 0 & 5 & 2 & 3 & $15(11.4)$ \\
\hline Staphylococcus epidermidis & 0 & 1 & 4 & 0 & 2 & 0 & 0 & 1 & 0 & 0 & $8(6.1)$ \\
\hline Total $(\%)$ & $3(4.0)$ & $20(30.0)$ & $11(16.0)$ & $3(4.0)$ & $30(45.0)$ & $6(9.0)$ & $11(17.0)$ & $19(29.0)$ & $8(12.0)$ & $21(31.0)$ & 132 \\
\hline
\end{tabular}

ATS: Accra Team Station; AB: Agbogbloshie; UNM: University of Ghana Night Market; SH: Shiashi; KB: Korle-Bu.

training course before authorization is given [16]. Findings from this study have revealed the need for emphasis on food safety education for street fruit vendors and hawkers in order to eradicate harm to consumers' health.

The consumption of vended foods is a risk for foodborne illness to consumers health because it is difficult to ascertain the hygienic processes the fruits were subjected to after harvesting, during processing, and before packaging [15]. This study found $62.2 \%$ and $60.7 \%$ of the vendors washed their watermelon and pawpaw, respectively, before slicing and packaging of the fruits, whilst $68.9 \%$ of the watermelon and $73.3 \%$ of the pawpaw vendors washed their knives before using them to slice the fruits. The contamination of the fruits in this study may have been introduced by the vendors using the same bucket of tap water to wash the fruits before slicing and packaging or using the same contaminated knife to cut the fruits into smaller pieces before displaying or selling them to customers $[16,17]$. Polyethylene bags which were the commonly used packages for the sliced fruits are waterproof and chemically resistant [17]. However, the sliced pawpaw and watermelon were still contaminated. Bacteria found in the polyethylene packaged sliced pawpaw and watermelon could also have been introduced from exposure of sliced watermelon to contaminated environments before they were processed and packaging [18].

Most studies usually report the presence of pathogens in fruits and vegetables, but the bacterial counts are often not documented [19]. Aerobic plate count can be used to monitor the hygienic quality of products throughout processing and distribution [20]. In this study, watermelon had a higher level of bacterial contamination $\left(2.6 \times 10^{5}-8.1 \times 10^{5} \mathrm{CFU} \mathrm{g}^{-1}\right)$ as compared to pawpaw $\left(3.7 \times 10^{4} \mathrm{CFU} \mathrm{g}^{-1}-7.1 \times 10^{4} \mathrm{CFU} \mathrm{g}^{-1}\right)$. This study's findings for pawpaw are comparable to that of Abisso et al. [21] study in South Ethiopia which reported a mean aerobic count of $4.2 \times 10^{2}-2.8 \times 10^{4} \mathrm{CFU} / \mathrm{ml}$ in papaya fruit juice. Our findings is in contrast to a study in Nigeria which reported a higher total aerobic count of $4.2 \times 10^{5}-1.4 \times 10^{6} \mathrm{CFU} \mathrm{g}^{-1}$ and $4.1 \times 10^{5} \mathrm{CFU} \mathrm{g}^{-1}-1.6 \times 10^{6} \mathrm{CFU} \mathrm{g}^{-1}$ for pawpaw and watermelon, respectively [5]. Furthermore, a higher mean aerobic count of $>6 \times 10^{5} \mathrm{CFU} \mathrm{g}^{-1}$ for pawpaw and watermelon has been reported in a similar study in Oman [22]. However, another study in Nigeria had reported a lower mean aerobic count of $1.5 \times 10^{2}-3.6 \times 10^{3} \mathrm{CFU} \mathrm{g}^{-1}$ in watermelon juice [23]. The International Commission on Microbiological Specifications for Foods (ICMSF) has proposed that ready-to-eat foods with mean aerobic counts between 0 and $10^{3}$ are acceptable, within $10^{4}-10^{5}$ are tolerable, and $\geq 10^{8}$ are unacceptable [24]. In this study's findings, the level of contamination could therefore be tolerable based on the recommended standards. In this study, watermelon had higher levels of bacteria occurrence than pawpaw. This could be due to the fact that watermelon grows close to the soil and may be susceptible to microbiological contamination from soil [25]. Furthermore, coliforms were detected in all samples analyzed, with an overall mean total coliform counts ranging between $1.2 \times 10^{3}$ and $3.1 \times 10^{4} \mathrm{CFU} \mathrm{g}^{-1}$. Watermelon had higher coliform counts of $1.6 \times 10^{4}-3.1 \times 10^{4} \mathrm{CFU} \mathrm{g}^{-1}$ as 
compared to pawpaw counts of $1.2 \times 10^{3}-8.1 \times 10^{3} \mathrm{CFU} \mathrm{g}^{-1}$. The possible reason for the higher coliform counts in watermelon may be due to the fact that watermelons are cultivated close to soil and this can enable easy contact of watermelon fruit with manure and irrigation water that may be contaminated.

In this study, Enterobacter sp. was the predominant bacteria isolated from both sliced watermelon $(28.4 \%)$ and pawpaw $(38.5 \%)$. This finding is slightly higher than the $21.4 \%$ prevalence in vegetables reported by Adebayo-Tayo and Okonko, [23] in Nigeria. A study with mango and papaya juices by Abisso et al. [21] in South Ethiopia has previously reported the presence of Enterobacter sp. Furthermore, in a Ghanaian review of ready-to-eat foods, Enterobacter sp. was observed as the predominant isolated bacteria. [26]. Other bacteria isolated from pawpaw and water melon were Citrobacter sp., Klebsiella sp., Klebsiella pneumoniae, Staphylococcus aureus, and Staphylococcus epidermidis which conforms to a previous study conducted in Nigeria [2, 27]. The presence of these bacteria on sliced fruits can be associated with exposure of the sliced fruits to the environment and contamination during processing [28, 29]. Activities such as slicing and packaging and transporting of fruits for sales have been found to be major risk factors of bacteria contamination [16]. A study with fruits and vegetables by Al-Kharousi et al. [22] in Oman revealed $60 \%$ of fruits and $91 \%$ of vegetables were contaminated with Enterobacteriaceae. The least bacteria isolated from the watermelon in that study was Pseudomonas sp. (1.5\%) and from the pawpaw was Staphylococcus epidermidis (1.5\%). A previous study conducted by Chukwu et al. [27] in Nigeria has also reported the presence of Pseudomonas aeruginosa, Klebsiella sp., Proteus sp., and Enterobacter sp. on precut pawpaw and watermelon. Pseudomonas sp., Klebsiella sp., Proteus sp., and Enterobacter sp. are bacteria commonly associated with plants, human skin, animals, and dairy products [30]. The presence of these bacteria in sliced watermelon and pawpaw may have been introduced by the contaminated hands of the vendors or by the use of contaminated water during washing and processing of the precut fruits $[31,32]$. The presence of Staphylococcus aureus in watermelon and pawpaw is in conformity with studies from Nigeria [2, 21]. Staphylococcus epidermidis and Staphylococcus aureus are normal flora of the body [33]. The presence of Staphylococcus epidermidis and Staphylococcus aureus in the sliced fruits could be as a result of contamination from hands used for the processing and packaging of the sliced fruit [27, 33]. Staphylococcus aureus is known to cause food poisoning and disease presentation is mostly characterized by nausea, vomiting, and diarrhoea [34]. In addition, the consumption of contaminated food harbouring staphylococcal endotoxins [34], produced when Staphylococcus aureus loads exceed $10^{5} \mathrm{CFU} \mathrm{g}^{-1}$ can also be very fetal [35]. While buying the fruits from the vendors, it was observed that the knife used in cutting the watermelon before packaging was not washed but kept in a polyethylene bag and repeatedly used throughout the day without intermittent washing. This practice might have introduced the bacteria onto the sliced pawpaw and watermelon. Generally, watermelon and pawpaw can be contaminated when the utensils used for processing the fruits are not cleaned appropriately [33].

\section{Conclusion}

Polyethylene packaged sliced watermelon and pawpaw sold on the streets in some selected sites in Accra were found to be contaminated with bacteria. Contamination of the fruits may have resulted from poor handling of the fruits during preparation. Therefore, street food vendors must be educated on food hygiene protocols and measures to improve microbial quality of street vended fruits. This is because safety of ready-to-eat foods and fruits is absolutely mandatory since it contributes to economic prosperity, boosts tourism and sustainable developments. Hence, food safety should be a major priority to all governments over the world.

\section{Strength and Weaknesses}

This study reports different microbial organisms are associated with some vended fruits (watermelon and pawpaw) in Ghana. Finding are vital in creating awareness on possible risks associated with the consumption of ready to eat packaged fruits. To a greater extent, this study has provided information to consummers and will intern assist in reducing the outbreak of diseases and help spark future studies that will aid in control of microbial contamination in street vended fruits in Africa.

The study focused on the total aerobic count, total coliform count, and identification of isolated bacteria types associated with polyethylene packed sliced pawpaw and watermelon sold by street vendors in Accra. The total aerobic count of bacteria was of marginal acceptable levels and could pose threat to the health of consumers. Limited samples from few vending sites in the Regional Capital of Ghana were tested thereby not allowing extrapolation of our results to other regions and to help determine the sources of contamination. The actual harm of the contaminated fruits to the consumers' health was not proven since they were not followed up to ascertain the effects of the bacteria contamination on their health.

\section{Data Availability}

The datasets used to support the findings of this study are available on reasonable request.

\section{Ethical Approval}

The study was approved by the Ethics Committee of the School of Biomedical and Allied Health Sciences, College of Health Sciences, University of Ghana, Legon (Ethics Identification Number: SAHS/10448661/AA/MLS/2016-2017).

\section{Consent}

Participation was voluntary, and consent was taken in accordance with the ethical committee's guidelines. 


\section{Conflicts of Interest}

The authors declare that no conflicts of interest exist.

\section{Acknowledgments}

The authors would like to express their gratitude to all the vendors who volunteered to take part in this study.

\section{References}

[1] G. I. Balali, D. D. Yar, V. G. Afua Dela, and P. Adjei-Kusi, "Microbial contamination, an increasing threat to the consumption of fresh fruits and vegetables in today's world," International Journal of Microbiology, vol. 2020, Article ID 3029295, 13 pages, 2020.

[2] E. Nwachukwu and H. U. Osuocha, "Microbiological assessment of ready to eat sliced pawpaw (Carica papaya) and watermelon (Citrullus lanatus) vended in Umuahia, Nigeria," International Journal of Current Microbiology and Applied Sciences, vol. 3, pp. 910-916, 2014.

[3] E. Nwachukwu, C. F. Ezeama, and B. N. Ezeanya, "Microbiology of polyethylene-packaged sliced watermelon (Citrullus lanatus) sold by street vendors in Nigeria," African Journal of Microbiology Research, no. 2, pp. 192-195, 2008.

[4] P. Mensah, K. Owusu-Darko, D. Yeboah-Manu, A. Ablordey, F. K. Nkrumah, and H. Kamiya, "The role of street food vendors in transmission of enteric pathogen's," Ghana Medical Journal, vol. 33, pp. 19-29, 2006.

[5] M. Gomez-Govea, L. Solis-Soto, N Heredia et al., "Analysis of microbial contamination levels of fruits and vegetables at retail in Monterrey, Mexico," Journal of Food Agriculture and Environment, vol. 10, pp. 151-156, 2012.

[6] A. O. Eni, I. A. Oluwawemitan, and O. U. Solomon, "Microbial quality of fruits and vegetables sold in Sango Ota. Nigeria," African Journal of Food Science, vol. 4, no. 2, pp. 291-296, 2010.

[7] CDC, Outbreak Surveillance Data, Center for Disease Control and Prevention (CDC), Atlanta, GA., USA, 2006.

[8] L. Byrne, I. Fisher, T. Peters et al., "A multi-country outbreak of Salmonella Newport gastroenteritis in Europe associated with watermelon from Brazil, confirmed by whole genome sequencing: october 2011 to January 2012," Euro Surveillance, vol. 19, no. 31, p. 6e13, 2014.

[9] G. A. Pesewu, J. N. Agyei, I. K Gyimah et al., "Bacteriological assessment of the quality of raw-mixed vegetable salads prepared and sold by street food vendors in korle-gonno, Accra metropolis, Ghana," Journal of Health Science, vol. 2, no. 2, pp. 560-566, 2014.

[10] E. Koneman, W. Winn, S. Allen, S. Janda et al., Koneman's Color Atlas and Textbook of Diagnostic Microbiology, pp. 367-373, Lippincott Williams \& Wilkins, Philadelphia, PA, USA, Sixth edition, 2006.

[11] S. Yildiz and T. Adom, "Evaluation of hygiene practices among street food vendors in Accra metropolis, Ghana," Elixir International Journal, vol. 41, pp. 5807-5811, 2011.

[12] E. S. Donkor, B. B. Kayang, J. Quaye, and M. L. Akyeh, "Application of the WHO keys of safer food to improve food handling practices of food vendors in a poor resource community in Ghana," International Journal of Environmental Research and Public Health, vol. 6, pp. 2833-2842, 2009.

[13] A. B. Mudey, N. Kesharwani, G. A. Mudey, R. C. Goyal, A. K. Dawale, and V. V. Wagh, "Health status and personal hygiene among food handlers working at food establishment around a rural teaching hospital in wardha District of Maharashtra, India," Global Journal of Health Science, vol. 2, no. 2, p. 198, 2010.

[14] A. Larbi, Food Hygiene and Safety Among Food Vendors in Ghana, Munich, GRIN Verlag, Munich, German, 2017, https://www.grin.com/document/494206.

[15] Food and Agricultural Organization of the United Nation; Street Food in Urban Ghana, A Desktop Review and Analysis of Findings and Recommendations from Existing Literature, 2016, http://www.fao.org/3/a-i5804e.pdf.

[16] European Commission, "Risk profile on the microbiological contamination of fruits and vegetables eaten raw," Report of the Scientific Committee on Food, Brussels, Belgium, 2002, https://ec.europa.eu/food/sites/food/files/safety/docs/sci-com_ scf_out125_en.pdf.

[17] K. Khalil, G. B. Lindblom, K. Mazhar, and B. Kaijser, "Flies and water as reservoirs for bacterial enteropathogens in urban and rural areas in and around Lahore, Pakistan," Epidemiology and Infection, vol. 113, no. 3, pp. 435-444, 1994.

[18] P. K. Oldring and U. Nehring, Packaging Materials 7: Metal Packaging for Foodstuffs, International Life Sciences Institute, Washington, DC, USA, 2007, https://ilsi.eu/publication/ packaging-materials-7-metal-packaging-for-foodstuffs/.

[19] A. N. Olaimat and R. A. Holley, "Factors influencing the microbial safety of fresh produce: a review," Food Microbiology, vol. 32, no. 1, pp. 1-19, 2012.

[20] M. J. Allen, S. C. Edberg, and D. J. Reasoner, "Heterotrophic plate count bacteria-what is their significance in drinking water?" International Journal of Food Microbiology, vol. 92, no. 3, pp. 265-274, 2004.

[21] T. G. Abisso, B. C. Gugero, and Y. H. Fissuh, "Physical quality and microbiological safety of some fruit juices served in cafes/ juice houses: the case of hossana town, southern Ethiopia," Journal of Nutrition \& Food Sciences, vol. 8, no. 3, pp. 1-5, 2018.

[22] Z. S. Al-Kharousi, N. Guizani, A. M. Al-Sadi, I. M. Al-Bulushi, and B. Shaharoona, "Hiding in fresh fruits and vegetables: opportunistic pathogens may cross geographical barriers," International Journal of Microbiology, vol. 2016, Article ID 2125070, 14 pages, 2016.

[23] B. C. Adebayo-Tayo and I. Okonko, "Microorganisms associated with spoilage of stored vegetables in Uyo metropolis, AkwaIbom state, Nigeria," Nature and Science, vol. 10, no. 8, 2012.

[24] ICMSF (International Commission on Microbiological Specification for Food), Sampling for microbiological analysis, principles and specification application, University of Toronto Press, Toronto, Canada, 1996.

[25] J. C. Heaton, "Microbial contamination of fruit and vegetables and the behaviour of enteropathogens in the phyllosphere: a review," Journal of Applied Microbiolgoy, vol. 104, pp. 613626, 2007.

[26] E. Yeleliere, S. J. Cobbina, and Z. I. Abubakari, "Review of microbial food contamination and food hygiene in selected capital cities of Ghana," Cogent Food \& Agriculture, vol. 3, no. 1, Article ID 1395102, 2017.

[27] O. O. Chukwu, O. A. Olabode, A. A. Chukwuedo, E. G. Umoh, and M. K. Esiekpe, "Bacteriological evaluation of pre-cut fruits sold in Kano metropolis, Kano State, Nigeria," East Afr J Public Health, vol. 6, no. 1, pp. 51-54, 2009.

[28] N. Barro, A. R. Bello, A. Savadogo, C. A. T. Ouattara, A. Iiboudo, and A. S. Traore, "Hygienic status assessment of dish washing waters, utensils, hands and pieces of money 
from street food processing sites in Ouagadougou (Burkina Faso)," African Journal of Biotechnology, vol. 5, pp. 1107-1112, 2006.

[29] FAO/World Health Organization, Report of a Joint FAO/ WHO Workshop., FAO/World Health Organization, Geneva, Switzerland, 2004, https://apps.who.int/iris/bitstream/ handle/10665/43143/9241592818_eng.pdf.

[30] J. W. Buck, R. R. Walcott, and R. L. Beuchat, "Recent trends in microbiological safety of fruits and vegetables," Plants Health Progress, vol. 1, pp. 1-10, 2013.

[31] S. Y. Daniyan and C. Q. Ajibo, "Microbiological examination of selected fruit sold in Minna metropolis," International Research Journal of Pharmacy, vol. 2, no. 7, pp. 124-129, 2011.

[32] A. Bowen, A. Fry, G. Richards, and L. Beauchat, "Infections associated with cantaloupe consumption: a public health concern," Epidemiology and Infection, vol. 134, no. 4, pp. 675-685, 2006.

[33] D. Weldezgina and D. Muleta, "Bacteriological contaminants of some fresh vegetables irrigated with awetu river in jimma town, southwestern Ethiopia," Advances in Biology, vol. 2016, Article ID 1526764, 2016.

[34] N. Balaban and A. Rasooly, "Staphylococcal enterotoxins," International Journal of Food Microbiology, vol. 61, no. 1, pp. 1-10, 2000.

[35] S. Derzelle, F. Dilasser, M. Duquenne, and V. Deperrois, "Differential temporal expression of the staphylococcal enterotoxins genes during cell growth," Food Microbiology, vol. 26, no. 8, pp. 896-904, 2009. 